Article

\title{
The Persisting Influence of Edge on Vegetation in Hemiboreal Alnus Glutinosa (L.) Gaertn. Swamp Forest Set-Asides Adjacent to Recently Disturbed Stands
}

\author{
Līga Liepa ${ }^{1, *}$, Zigmārs Rendenieks ${ }^{2} \mathbb{D}, \bar{A}^{-}$is Jansons ${ }^{3}$, Inga Straupe ${ }^{1} \mathbb{D}$, Edgars Dubrovskis $^{1}$ \\ and Olga Miezīte ${ }^{1}$ \\ 1 Department of Silviculture, Latvian University of Life Sciences and Technologies, Akadēmijas 11, \\ LV-3001 Jelgava, Latvia; inga.straupe@llu.lv (I.S.); edgars.dubrovskis@llu.lv (E.D.); \\ olga.miezite@llu.lv (O.M.) \\ 2 Department of Geography and Earth Sciences, University of Latvia, Jelgavas 1, LV-1004 Riga, Latvia; \\ zigmars.rendenieks@lu.lv \\ 3 Latvian State Forest Research Institute Silava, Rigas 111, LV-2169 Salaspils, Latvia; aris.jansons@silava.lv \\ * Correspondence: liga.liepa@llu.lv
}

Received: 4 September 2020; Accepted: 6 October 2020; Published: 12 October 2020

\begin{abstract}
To increase set-aside areas and protect biodiversity values in managed hemiboreal forest landscapes, small forest parcels called Woodland Key Habitats have been designated in Baltic and Nordic countries. The aim of this study was to investigate the persisting influence of the edge on vegetation dynamics for young, medium-old and old edges in Alnus glutinosa (L.) Gaertn. Woodland Key Habitats. All of these edges are adjacent to recently disturbed (clear-cut) stands. We surveyed edge influence on vegetation in bryophyte, herbaceous, shrub and tree layers in 90 plots in 30 set-aside forest stands in Southern Latvia. We tested the differences in the number of species and projective coverage in all vegetation layers, but plant functional types were examined-separately in the herbaceous layer. We found that edge influence in protected forest stands of $A$. glutinosa swamp forests reflects strong changes in vegetation and plant functional types in the herbaceous layer mostly up to 20 years after clear-cut disturbance in adjacent stands. The greatest differences were between young edges ( $\leq 20$ years) and old edges ( $\geq 41$ years), but there were very few significant differences between medium-old (21-40 years) and old edges which signifies more rapid changes in the early stages of edge influence and gradual stabilization of vegetation later on. We found that in edges adjacent to recently disturbed stands (up to 20 years), significantly less rare and indicator epiphytic lichen species occur, but this occurrence increases over time and edge influence is no longer present beyond 20 years after disturbance. Changes in vegetation and species occurrence found in our study indicated the need to plan the allocation of set-aside patches in production forest landscapes to ensure connectivity over longer period of time. Careful planning of clear-cuts in neighboring areas over time can significantly reduce the impact of edge effect on these set-asides.
\end{abstract}

Keywords: black alder; hemiboreal forests; epiphytic lichens; plant functional types; clear-cut edges; edge effect

\section{Introduction}

In natural landscapes edges are characterized as transition zones between two adjacent habitats or areas formed by natural disturbances. Historically, edge-related studies have been widely focused on the term "ecotone" which is often created naturally or due to human impact between two adjacent 
plant communities. However, edge effects induce changes for several ecological conditions which reflect differences between edges and interior habitat [1]. Edge effects may generate positive, negative or neutral impact at species, ecosystem or landscape levels [2]. It is known that a large portion of landscapes might be influenced by edge effects, initiated by human-induced activities [3]. Therefore, we examined natural and human-induced edges separately. Indeed, few studies have dealt with the comparison of natural and anthropogenic edges [4-7]. More studies have been carried out in order to test human-induced edge influence, especially, on tropical forest ecosystems. Examples include vegetation assessment [8], biophysical characteristics [9], and environmental parameters [10]. There are fewer studies on edge effect responses in boreal forests, such as vegetation differences between clear-cut and fire edges [2,6], and edge influence on epiphytic species [11-13] or bryophytes in the ground layer [14].

Edge effects reflect changes in biotic and abiotic conditions close to stand edge and usually edge habitats are different in composition or structure compared to habitats in core areas. A number of studies on edge effects reflect changes in vegetation composition on average up to $50 \mathrm{~m}$ from the stand edge and the influence of the edge may persist for several years [1,15]. Edge effects might come with positive, negative or neutral biotic responses [1].

The investigation of human-induced edge effects in ecology has been a commonly studied area in recent decades in the field of ecology [16]. Specifically, edge influence o has offen been described in terms of edge origin, forest type, and edge age and edge length. Until now, relatively few studies have dealt with the persistence of edge influence on vegetation in forests [16], importantly, there is a lack of studies on vegetation in swamp forests and on bryophyte layer species or understory vegetation. Few studies have investigated functional changes in herbaceous layer in response to plant functional types which describe the consequences of created edges $[13,17,18]$.

In order to preserve small, ecologically valuable habitats in production forest landscape, the Woodland Key Habitat (WKH) concept has been created in Baltic and Scandinavian countries [19,20]. WKHs were designated on the basis of stand age, the diversity of structural elements and the occurrence of indicator species [21]. Commonly, WKHs are small parcels of naturally regenerated stands with a mature or over-mature age, with average area of 0.7 to 4.6 ha [22]. Due to their small size, WKHs are often strongly influenced by edge effects [23]. Since WKHs are highly fragmented, they are strongly influenced by changes in biotic conditions.

WKHs present one conservation approach to the set-aside concept, making up functional networks which facilitate landscape connectivity with other protected areas. This approach is well-known and is commonly practiced in the forested landscapes of Scandinavian and Baltic countries.

Fennoscandian deciduous swamp forests are characterized as the most diverse forest types in the hemiboreal biome with regards to high species diversity and specific ecological conditions [24]. In these forests, the tree layer is dominated by Alnus glutinosa, mixed with Betula pubsecens Ehrh. Some persistent conditions, such as stable microclimate, diverse structural features and mosaic structure with raised hummocks, are important characteristics which provide diverse local conditions with various different niches for many organism groups [25]. Hummocks with a plant detritus layer and overflooding depressions create favorable conditions for diverse and mosaic-type vegetation, rich in hydrophyes, and hygrophytes, and, on the tops of hummocks, typical boreal and shade-tolerant species occur [26]. A. glutinosa stands are affected by seasonal flooding [27] when the water level fluctuates and the flow of water brings in organic matter. Thus, this provides an opportunity to investigate edge influence on vegetation, since these sites have a stable microclimate which is specific for many organism groups. Therefore, for this study we selected stands which are designated as WKHs and have been voluntarily set-aside for almost three decades.

The aim of this study was to investigate and evaluate the persisting influence of edge on vegetation dynamics for young, medium-old and old edges in A. glutinosa WKHs in Southern Latvia. All of these edges are adjacent to recently disturbed (clear-cut) stands. We set out two objectives: (1) to assess vegetation and epiphytic lichens in A. glutinosa swamp forests; and, (2) to analyze plant functional 
types for species in herbaceous layer. We hypothesized that edge influence from forest harvesting in stands adjacent to $A$. glutinosa swamp forests diminishes over time.

\section{Materials and Methods}

The study was conducted in Southern Latvia (Figure 1) which is a part of the hemiboreal zone [28]. According to the data of the National Forest Inventory, forest areas cover approximately $54 \%$ of the terrestrial land in Latvia. Forests are dominated by coniferous trees (51.9\%)—Scots pine Pinus sylvestris L. and Norway spruce Picea abies (L.) H. Karst.; deciduous species are common as well, comprising 47.2\% - mostly birch species (Betula pendula Roth and Betula pubescens Ehrh.), European aspen (Populus tremula L.), grey alder (Alnus incana (L.) Moench), black alder (Alnus glutionosa (L.) Gaertn.). Other broad-leaved trees are less common $(0.9 \%)$ and occur close to the northern limit of their distribution range. Forests dominated by A. glutinosa constitute approximately $7 \%$ of forests in Latvia. The climate in our study area is maritime temperate: the mean temperature in January is $-5^{\circ} \mathrm{C}$ and $+16^{\circ} \mathrm{C}$ in July, and annual precipitation varies from 550 to $850 \mathrm{~mm}$. Elevation in studied sites ranges from 0 to $20 \mathrm{~m}$ a.s.1. [29].

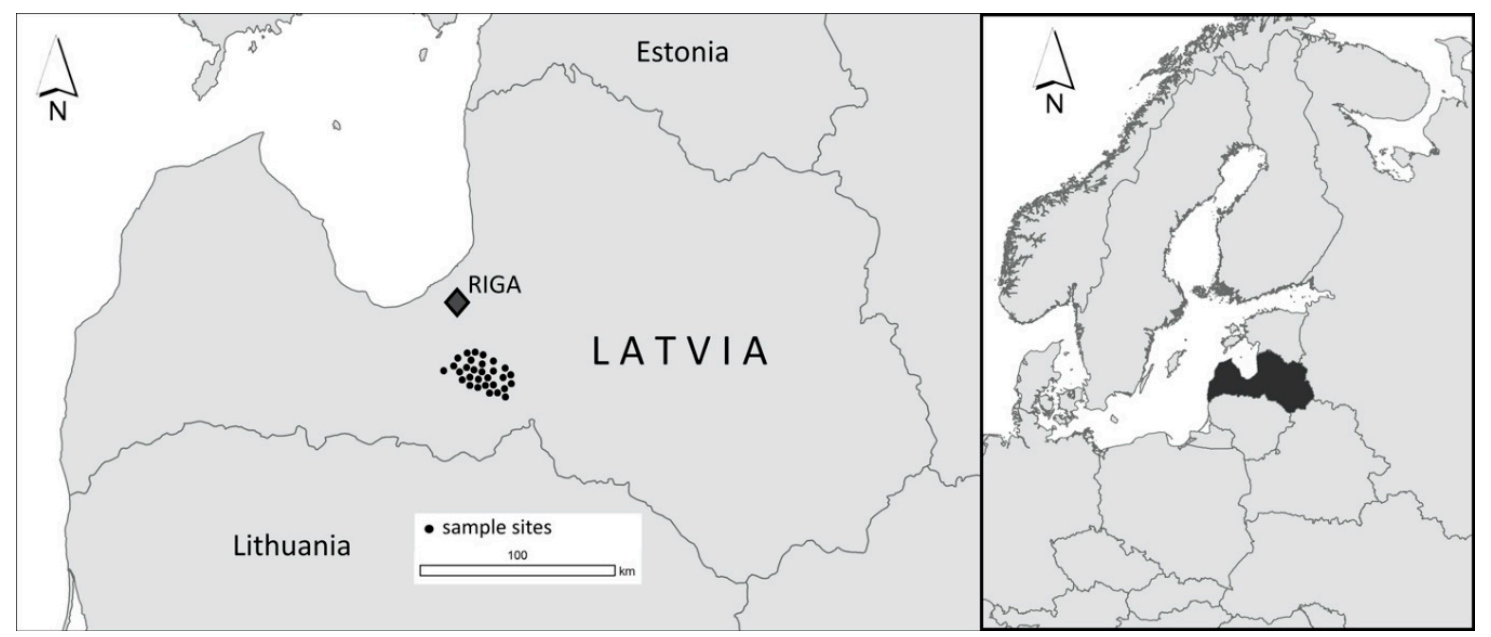

Figure 1. Locations of study sites in Latvia.

In total 30 forest stands were surveyed. We used a space-for-time substitution approach by selecting forest stands adjacent to clear-cuts of different age to infer the temporal trends of edge persistence [30]. All studied forest stands are dominated by A. glutinosa and, according to Latvian forest typology, they correspond to Dryopterioso-caricosa and Filipendulosa types which are characterized by wetland forest types on soils with peat layer thickness $>30 \mathrm{~cm}$ [31]. These types correspond to order: Alnetalia glutinosae Tx. 1937 em. Oberd. 1953, alliance: Alnion glutinosae (Malc. 1929) Meijer Drees 1936. em. Th. Mull. et. Gors 1958, association: Carici elongatae-Alnetum Schwick. 1933 and Sphagno squarossi-Alnetum Sol.-Gorn. Ex. Pried. 1997 forests in the Baltic Region [25]. Studied forest stands represent over-mature A. glutinosa swamp WKHs with ages ranging from 84 to 129 years (average age 97 years). Selection of study areas was limited, because all stands are protected set-asides, and any type of logging there is prohibited. In this region A. glutinosa is less studied and is concentrated in local micro-depressions. The selection of A. glutinosa swamp forests was based on the fact that these sites have a specific microclimate, which facilitates many organism groups and these sites might be sensitive to any interventions in adjacent areas. All clear-cut edges (with final felling in the adjacent stand) were facing south or south-west. We selected stands with edges adjacent to clear-cuts with different time since the final felling: young ( $\leq 20$ years), medium-old ( $21-40$ years), and old ( $\geq 41$ years) (Table A1).

In each studied stand, three equally-spaced plots were established with size of $20 \times 10 \mathrm{~m}\left(200 \mathrm{~m}^{2}\right)$. In total 90 sample plots represented young edges (30 plots), medium-old (30) and old edges (30). 
Each sample plot represented an independent sampling unit. In all sample plots we assessed vegetation by layers and estimated the occurrence of protected and WKH indicator species of epiphytic lichens [32].

We used the Braun-Blanquet approach [33] to survey and describe plant communities by layers: the total projective coverage of bryophyte, herbaceous, shrub and tree layers as well as the coverage of each separate species was estimated as a percentages (\%) in the bryophyte layer (E0), herbaceous layer (E1) (including plants, dwarf shrubs, shrub and tree species up to height $0.5 \mathrm{~m}$ ), shrub layer (E2) (shrub and tree species at height from 0.5 to $7.0 \mathrm{~m}$ ), and tree layer (E3) (tree species from height $7.0 \mathrm{~m}$ ). The nomenclature for vascular plants follows Gavrilova, Šulcs [34], and that for bryophyte layer species followed Ābolina et al. [35]. We assessed species diversity according to the number of all species per vegetation layer in terms of Shannon-Wiener formula and thereafter the Pielou evenness index was calculated [36].

We used plant functional types to characterize all species in the herbaceous layer by Raunkiaer life history forms [37], plant strategy groups (C-S-R) [38], dispersal types of plant seeds and spores. We obtained preferable habitat indicative groups from the following databases: LEDA [39], BIDS EcoFlora [40] and "Flora for vascular plants in Central Russia" [41]. Habitat groups included boreal, nemoral, nitrophilous, adventive (species of alien origin including invasive plants or non-forest species) [41], meadow, and swamp forest species. We characterized plant trait groups using numbers of species $(\mathrm{N})$.

Plant indicator values for environmental factors (light, moisture, soil reaction $(\mathrm{pH})$ and $\mathrm{N}$ for soil nitrogen) were extracted from Ellenberg indicator scales [42]. We considered only light demanding species with indicator value $\geq 6$. The indicator numbers were calculated using projective coverage for each species.

We surveyed epiphytic lichens separately from vegetation, because they serve as indicator species for designating WKHs. We classified species of epiphytic lichens as rare according to the regulation of list of protected species in Latvia [43]. We extracted WKH indicator species from the list of forests with height conservation value corresponding to the State Forest service [32]. In all sample plots we surveyed the occurrence of protected epiphytic lichens and WKHs indicator species on randomly chosen A. glutinosa trees $(n=3$ in each sample plot with size of $10 \times 20 \mathrm{~m}$ ) at the height of $0.5 \mathrm{~m}$ and $1.5 \mathrm{~m}$ from the ground (" + "- the presence of species and " - "- the absence of species). The nomenclature for lichens followed Ābolina et al. [35].

In this study we used descriptive methods for data of vegetation survey (mean, standard error). Statistical distributions were assessed graphically (histograms) and analytically (Shapiro-Wilk test of normality). According to the results (symmetrical distribution of data), parametric methods were chosen to assess the differences for forest structural features and vegetation data. ANOVA test was used to estimate the significant variations between gradation classes (adjacent forest stand, distance from forest stand edge) and Tukey's HSD test. A risk level of $5 \%(p<0.05)$ was used to define statistical significance.

The numbers of protected epiphytic lichens and WKH indicator species were tested for normality with the Shapiro-Wilk test. Non-parametric Kruskal-Wallis rank sum test was used to find significance between groups. Pair-wise comparisons were used with Wilcoxon signed rank test with Bonferroni adjusted $p$-values (at confidence level $p=0.05$ ). Statistical calculations were made in R version 3.5.0 [44].

\section{Results}

\subsection{Projective Coverage}

We found that species projective coverage differed notably between young ( $\leq 20$ years), medium-old (21-40 years) and old ( $\geq 41$ years) edges for all vegetation layers (Figure 2$)$. 


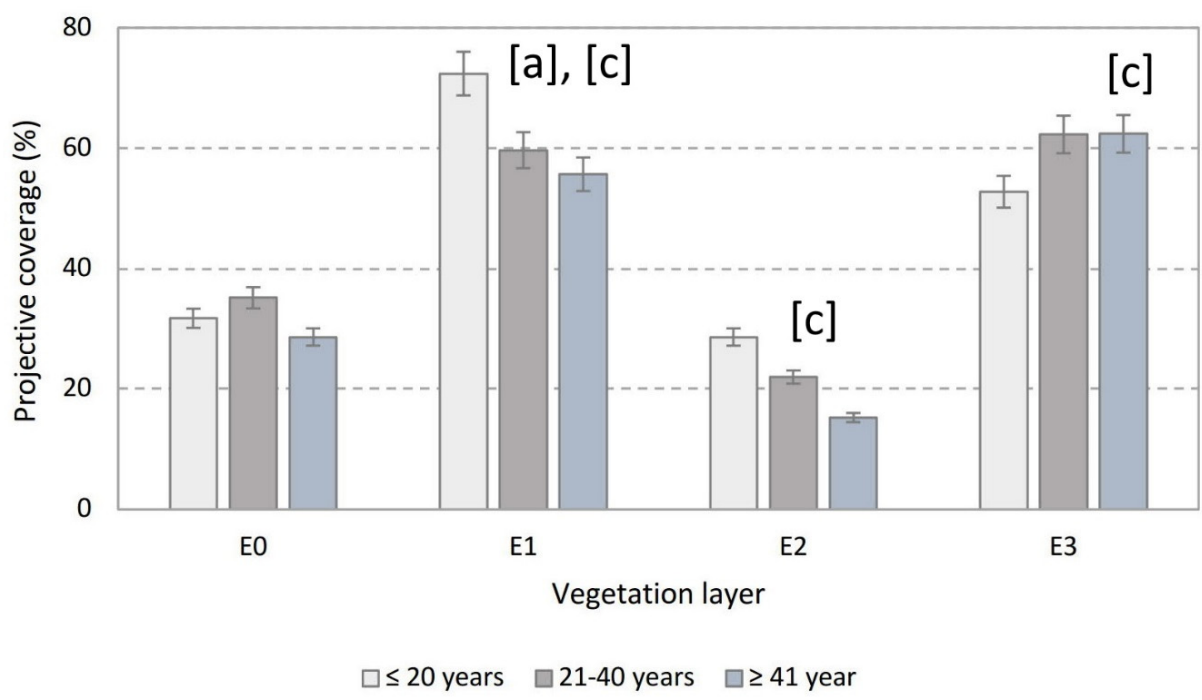

Figure 2. Projective coverage (\%) of species by vegetation layer (E0-bryophyte layer, E1—herbaceous layer, E2 - shrub layer and E3-tree layer) in young ( $\leq 20$ years, medium-old (21-40 years) and old (>41 years) edges. Significant differences shown with letters: (a) - between young and medium old edges, (b) - between medium-old and old edges and (c) - between young and old edges $(p<0.05)$. $n=90$, values are means \pm standard error is shown.

We did not find significant differences in projective coverage between young, medium-old and old edges at E0 vegetation level (Table 1). At E1 level, projective coverage was significantly higher in young edges compared to medium-old $(p<0.05)$ and old $(p<0.05)$ edges. At the E2 layer, projective coverage was significantly $(p<0.05)$ higher in young edges compared to old ones, but at the E3 layer, old edges had significantly $(p<0.05)$ higher projective coverage than young edges.

Table 1. Summary of ANOVA results $(n=90)$ for species projective coverage, number of species and plant functional types (including habitat groups, seed dispersal agents, plant strategy groups, Raunkiaer life history forms) and environmental factors.

\begin{tabular}{|c|c|c|c|c|}
\hline \multirow{2}{*}{ Variable } & \multirow{2}{*}{ Species Group } & \multicolumn{3}{|c|}{ Adjacent Stand Age Group } \\
\hline & & $0-20$ vs $20-40$ & $20-40$ vs $>41$ & $0-20$ vs $>41$ \\
\hline \multirow{4}{*}{ Projective coverage } & E0 & $\mathrm{ns}$ & ns & ns \\
\hline & E1 & $p<0.05 \uparrow$ & ns & $p<0.05 \uparrow$ \\
\hline & E2 & $\mathrm{ns}$ & ns & $p<0.05 \uparrow$ \\
\hline & E3 & ns & ns & $p<0.05 \downarrow$ \\
\hline \multirow{5}{*}{ Number of species } & E0 & $p<0.05 \uparrow$ & $p<0.05 \uparrow$ & ns \\
\hline & E1 & $p<0.05 \uparrow$ & ns & $p<0.05 \uparrow$ \\
\hline & E2 & $\mathrm{ns}$ & ns & ns \\
\hline & E3 & $p<0.05 \uparrow$ & ns & $p<0.05 \uparrow$ \\
\hline & Total & $p<0.001 \uparrow$ & ns & $p<0.001 \uparrow$ \\
\hline \multicolumn{5}{|c|}{ Plant functional types (E1 layer) } \\
\hline \multirow{6}{*}{ Habitat group } & Boreal species & ns & ns & ns \\
\hline & Nemoral species & $p<0.05 \uparrow$ & ns & $p<0.05 \uparrow$ \\
\hline & Nitrophilous species & $p<0.001 \uparrow$ & ns & $p<0.05 \uparrow$ \\
\hline & Adventive species & $p<0.05 \uparrow$ & ns & $p<0.05 \uparrow$ \\
\hline & Meadow species & $\mathrm{ns}$ & ns & ns \\
\hline & Swamp forest species & $p<0.05 \uparrow$ & ns & $p<0.001 \uparrow$ \\
\hline \multirow{4}{*}{ Seed dispersal agent } & Wind & $p<0.05 \uparrow$ & ns & ns \\
\hline & Water & $\mathrm{ns}$ & ns & ns \\
\hline & Other animals & $p<0.05 \downarrow$ & ns & $p<0.05 \downarrow$ \\
\hline & Birds & ns & ns & $p<0.001 \uparrow$ \\
\hline
\end{tabular}


Table 1. Cont.

\begin{tabular}{|c|c|c|c|c|}
\hline \multirow{2}{*}{ Variable } & \multirow{2}{*}{ Species Group } & \multicolumn{3}{|c|}{ Adjacent Stand Age Group } \\
\hline & & $0-20$ vs $20-40$ & $20-40$ vs $>41$ & $0-20$ vs $>41$ \\
\hline \multirow{4}{*}{ Plant strategy group } & $\mathrm{C}$ & $p<0.05 \uparrow$ & ns & $p<0.05 \uparrow$ \\
\hline & CS & $\mathrm{ns}$ & ns & \\
\hline & $\mathrm{CR}$ & $p<0.05 \uparrow$ & ns & $p<0.05 \uparrow$ \\
\hline & CSR & $p<0.001 \uparrow$ & ns & $p<0.001 \uparrow$ \\
\hline \multirow{4}{*}{ Raunkiaer life history form } & Phanerophyte & $p<0.05 \uparrow$ & $p<0.05 \uparrow$ & ns \\
\hline & Hemicryptophyte & $p<0.001 \uparrow$ & ns & $p<0.05 \uparrow$ \\
\hline & Therophyte & ns & ns & ns \\
\hline & Geophyte & ns & ns & ns \\
\hline \multirow{4}{*}{ Environmental factor } & Temperature & $\mathrm{ns}$ & ns & ns \\
\hline & Moisture & ns & ns & ns \\
\hline & Soil pH & $p<0.05 \uparrow$ & ns & ns \\
\hline & Light-demanding species $(\geq 6)$ & $p<0.001 \uparrow$ & ns & $p<0.001 \uparrow$ \\
\hline
\end{tabular}

Vegetation layers: E0-bryophyte, E1-herbaceous, E2-shrub and E3-tree layer. Plant strategy groups: C (competitive), CS (competitive-stress tolerant), CR (competitive-ruderal), CSR (competitive-stress tolerant-ruderal). $p<0.05$ denotes statistically significance difference, ns-non-significant.

Overall, projective coverage was significantly higher in young edges versus medium-old edges. We found no significant differences in projective coverage between medium-old and old edges at any layer.

\subsection{Species Richness, Shannon-Wiener Index and Evenness}

We found the highest species richness at E1 layer at young edges (Figure 3).

At the E0 layer species richness was below 10, and medium-old edges had slightly higher richness compared to young and old ones. At the E1 layer, young edges had notably higher species richness and Shannon-Wiener index values compared to medium-old and old edges. At the E2 and E3 vegetation layers, species richness was generally low and exhibited slight differences between young, medium-old and old edges. In our results, Shannon-Wiener index values generally correspond to species richness values.

Total species richness in all vegetation layers combined clearly indicates that there is a gradual decline in the number of species from young edges (younger than 20 years) to old edges (older than 41 years). As for Pielou's evenness index values, they did not show marked differences between edges of different age, with the exceptions of young edges at the E1 layer which had a higher value than medium-old and old edges and old edges at E3 layers with lower value compared to young and medium-old edges at this vegetation layer. Similarly, the number of species was tested between young, medium-old and old edges and we found the majority of significant $(p<0.05)$ differences between young and medium-old edges. The number of species was significantly higher in young edges at layers E0, E1 and E3 compared to medium-old edges. We found no significant differences at the E2 layer. Only at the E0 layer number of species was significantly higher in medium-old edges compared to old ones. Between young and old edges, the number of species was significantly higher in young ones, but only at the E1 and E3 layers.

With all vegetation layers considered together, we found that young edges had significantly higher number of species compared to medium-old $(p<0.001)$ and old $(p<0.001)$ edges, but we found no difference between medium-old and old edges. 

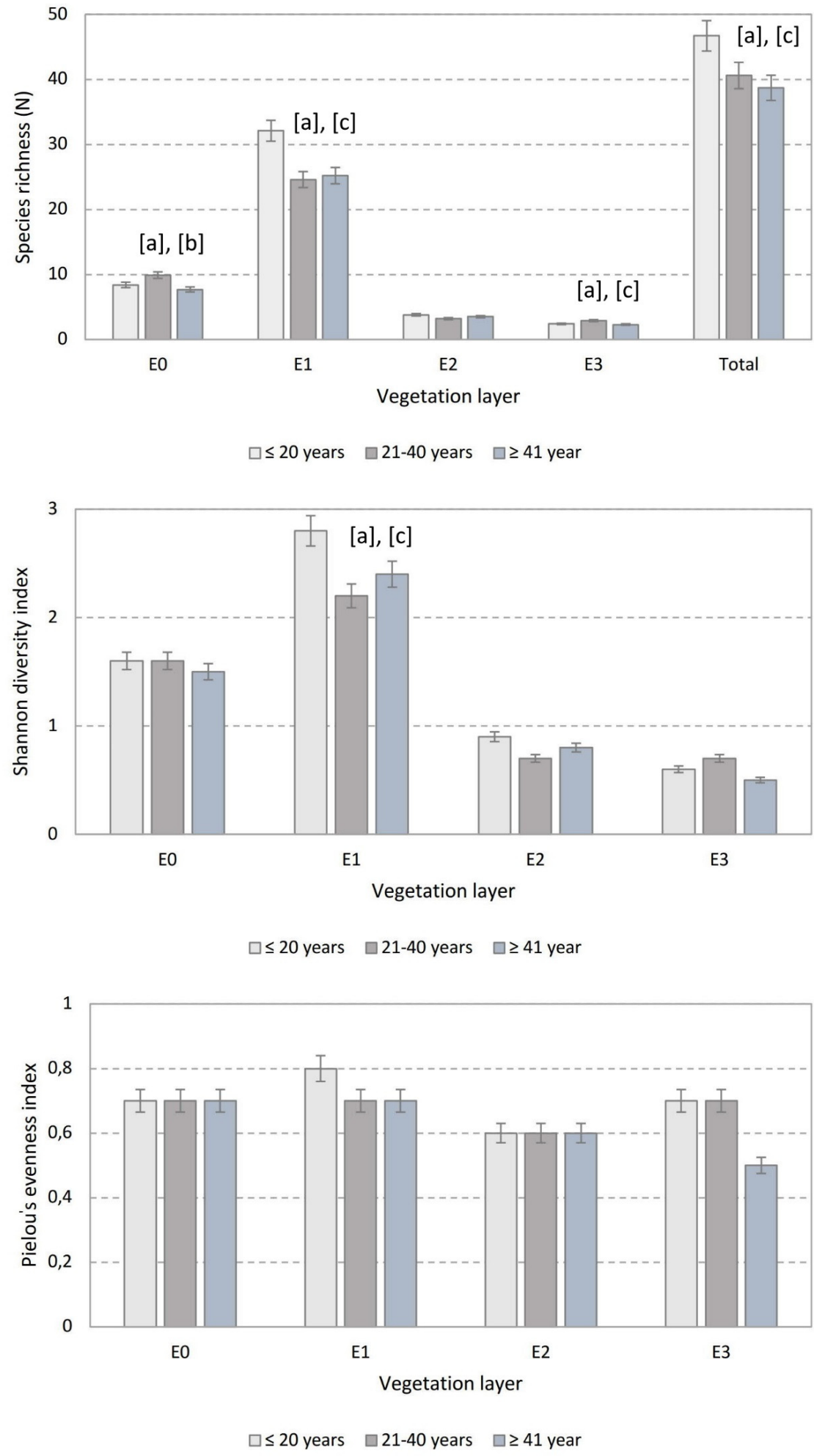

Figure 3. Species richness (upper part), Shannon-Wiener index (middle) and evenness (bottom) by vegetation layer in young ( $\leq 20$ years, medium-old (21-40 years) and old ( $>41$ years) edges. Significant differences are shown with letters: (a) - between young and medium old edges, $(\mathbf{b})$ - between medium-old and old edges and (c) - between young and old edges $(p<0.05) . n=90$, values are means \pm standard error is shown. 


\subsection{Plant Functional Types}

Habitat group. Plant functional types were tested only for the E1 layer (Table A2). Species number was not significant $(p<0.05)$ for boreal species between young, medium-old and old edges. For nemoral (pertaining to temperate forest biome) species, young edges had a significantly higher number of species compared to medium-old and old edges, and then we found the same relationships for nitrophilous, adventive and swamp forest $(p<0.001)$ species. Medium-old and old edges showed no significant differences in the number of species.

Seed dispersal agent. Among tested seed dispersal agents, wind propagated a significantly $(p<0.05)$ higher number of species in young edges compared to medium-old ones. No edges showed significant differences with old edges in terms of the number of wind-propagated species. For bird distributed plants, species number was significantly higher in young edges compared to old ones. Species propagating with the help of other animals were more numerous in old edges compared to young ones $(p<0.05)$ and medium-old ones $(p<0.05)$. In the water group no significant differences were found.

Plant strategy groups. Plant strategy groups tested for the E1 layer showed that in young edges the number of competitive (C)-strategy species was significantly higher compared to medium-old and old edges $(p<0.05)$. We found the same relationships for competitive-ruderal (CR)-type species $(p<0.05)$ and competitive-stress tolerant_ruderal (CSR) species $(p<0.001)$. We found no significant relationships between medium-old and old edges in terms of the number of species.

Raunkiaer lifeforms. We found a significantly higher number of phanerophyte species in young edges compared to medium-old edges $(p<0.05)$ and between medium-old and old edges $(p<0.05)$. Relationships between young and old edges were not significant. For hemicryptophytes, we found the number of species to be higher in young edges compared to medium-old ones $(p<0.001)$ and old ones $(p<0.05)$, but there were no significant differences between medium-old and old edges. For the remaining lifeforms — therophytes and geophytes—we found no significant differences in the number of species.

Environmental factors. For temperature and moisture factors, we found no significant $(p<0.05)$ differences (Table 1$)$. Soil $\mathrm{pH}$ was significantly $(p<0.05)$ higher in young edges compared to medium-old edges, but there were no significant differences with old edges. We tested only subplots with Ellenberg light values $\geq 6$ which correspond to light-demanding species. From these instances, values in young edges were significantly higher compared to medium-old edges $(p<0.05)$ and old edges $(p<0.05)$. We found no significant differences between edges of various age with regards to temperatures and moisture values.

\subsection{Proportion of Protected Epiphytic Lichen Species and WKH Indicator Species}

In total, four crustose lichen indicator species were found in the studied A. glutinosa forest stands. Three of them were rare and protected species in Latvia (Arthonia leucopellea, Arthonia spadicea and Arthonia vinosa), and one was a common indicator species, Graphis scripta. Two species were found in study sites with adjacent young edges and four species were found in sites with adjacent old edges (Figure 4).

We also measured the proportion of WKH indicator species for edges with various age. Species with the highest proportion was $A$. spadicea with $>60 \%$ in young edges and $>85 \%$ in medium-old and old edges. The only other species which was found in young, medium-old and old edges was G. scripta, reaching $20 \%$ in young edges, $65 \%$ in medium-old and $40 \%$ in old edges (Figure 4). A. leucopellea occurred only in medium-old and old edges, but $A$. vinosa occurred only in old edges. We found that young edges had significantly $(p<0.001)$ fewer protected and indicator species compared to medium-old edges, and young edges had significantly $(p<0.001)$ fewer such species compared to old edges. 


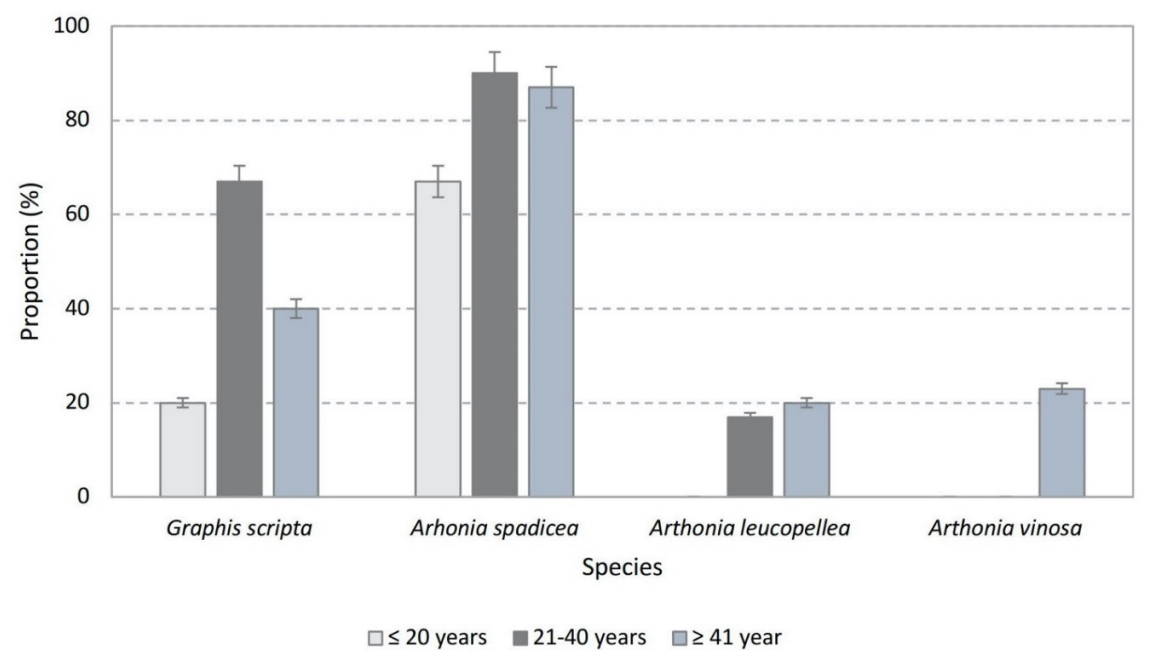

Figure 4. Proportion of Woodland Key Habitat indicator species in young ( $\leq 20$ years, medium-old (21-40 years) and old ( $>41$ years) edges.

\section{Discussion}

We found that the persisting influence of the edge on A. glutinosa swamp forest set-asides shows strong changes in vegetation and plant functional types in herbaceous layer mostly up to 20 years after the harvest of adjacent stands, but some of tested values, for instance, the number of epiphytic lichen species reflect significant changes even beyond 41 years after anthropogenic disturbances in adjacent stands. We found the greatest differences between edge habitats in young edges (i.e. soon after the introduction of edge effects) and old edges, but very few significant differences between medium-old and old edges (late after the introduction of edge effects) which signifies the more rapid changes in the early stages of edge influence and gradual stabilization of vegetation later on.

The influence of edge persistence on bryophyte layer. Species in the bryophyte layer are little affected by edge effects, and this is not explained by disturbance in the adjacent stand alone. The results show that significantly fewer species are found in A. glutinosa forests in young and old edges, compared to medium-old edges. This is explained by specific microclimatic conditions; however, in contrast to herbaceous species, mosses and bryophytes may colonize only patches on microrelief hummocks which is not covered by seasonal water level fluctuation. Other studies showed that edge influence on the number of species at the ground layer remains for more than 55 years after the disturbance event in the adjacent stand [45], but persistence of edge influence on bryophyte layer in hemiboreal pine stands was detected up to 40 years after clearcutting [46]. Different environmental conditions and substrates can cause variability in species' responses to edge influence [18]. For instance, bryophyte layer species Rhytidiadelphus triquetrus and Plagiomnium ellpticum colonized desiccated open patches of bare ground in young edges and, over time, their projective coverage decreased with increasing age of adjacent stands.

Persistence of edge effects on herbaceous layer. Prominent differences among edge types were greater in species projective coverage and number in herbaceous layer by young edges, but this effect diminishes over time-it is weaker after 21 years from the disturbance in an adjacent stand. Generally, these changes are found in relation to the increase in number of species at herbaceous and shrub layers [47]. In fact, such changes are related to increased light availability $[47,48]$ and other microclimatic changes after the disturbance in the adjacent stand which have facilitated the advancement and presence of half-light and light-demanding species. Conversely, it has been found that in boreal and hemiboreal forests species have adapted to the influence of natural disturbances, for instance, gap dynamics and seasonal variation in groundwater level. As a result of this, stable plant communities have formed and other types of disturbances, like edge influence in these communities can have no impact on the number of species at the ground layer [7,49]. 
Plant functional types in herbaceous layer. The studied forests have significantly more nemoral, nitrophilous, swamp forest and adventive species which decrease during the first 20 years after the disturbance in the adjacent stand. Studies confirm that after disturbances the number of ruderal and adventive species increases, outcompeting typical forest understory species which can even temporally disappear [50,51]. Along with other plant species colonizing A. glutinosa forests in young edges, the number of C and CSR species increases significantly, but such effects are reduced in medium-old and old edges. Other studies confirmed that harvesting in adjacent stands increase the total number of species as well as the advance of competing vascular species [6]. We found significantly more anemochores (plants propagated by wind) and ornitochores (propagated by birds) in young edges. The number of anemochore species decreases in medium-old edges, but the number of ornitochores decreased in old edges, and even in this group of A. glutinosa forests we found a significantly higher number of zoochores (plants propagated by animals). For example, a study of Pelissier et al. [17] showed that in edges the number of anemochores, ornitochores and autochores increase. Species from harvested stands are known to advance into adjacent edges in significant numbers [52]. Increased numbers of ornitochores can be evidence of increased predation rate in edges and increased number of small mammals which facilitate seed propagation [53]. According to this, the number of phanerophytes often increase in edges [15], but we did not find a confirmation of this in our study. Larger numbers of zoochores in old edges may indicate the avoidance of mammals of younger, exposed edges. We found that there were more hemicryptophytes in young edges, but the number of these species decreases in the edges sites where the disturbance in adjacent stand was more than 20 years ago. The inclusion of the analysis of plant functional types in edge studies is beneficial, because they indicate species dynamics and change species interactions inside the stand.

The influence of edge persistence on shrub layer. Our study found that significantly higher shrub layer projective coverage is seen in A. glutinosa forests with young edges, while in forests with medium-old and old edges, this relationship was not present. Our findings are in line with results from other studies which imply that shrub species richness and coverage is higher along forest edges in tropical forests [54] and deciduous forests [47] compared to the interior. Other studies [55,56] have also showed that species richness and diversity in old edges at shrub layer do not indicate edge influence. Similarly, Harper and McDonald found that there was no significant difference in shrub layer richness between old and young clear-cut edges in aspen forest in Canada [57].

The influence of edge persistence on tree layer. Harvesting in adjacent stands influences the species richness at tree layer: our results show that smaller number of species occur in A. glutinosa forests in young edges, but it increases over time, and 20 years after the disturbance, there is no difference. The occurrence of $A$. glutinosa is significantly lower in young edges, but this effect decreases over time and is not present beyond 41 years after the disturbance in adjacent stand. This is explained by the fact that, after the disturbance in an adjacent stand, trees on the edges are more influenced by changes in microclimatic conditions and, therefore, trees are more often impacted by wind and tree projective coverage decreases.

The influence of edge persistence on WKH indicator species and protected epiphytic lichens. Epiphytic lichen species react negatively to changes in abiotic factors caused by harvesting in adjacent stands. This is also true in A. glutinosa forests, where the results show that in edges adjacent to recently disturbed stands (up to 20 years), fewer less rare and indicator species occur, but this occurrence increases over time and is no longer present, beyond 20 years after disturbance. We found higher occurrence of rare species in $A$. glutinosa forests in old edges ( $\geq 41$ years after the disturbance in adjacent stand). Previous studies indicated that edge effects are gradually decreasing with increasing distance from the edge [58]. In addition, edge effects are induced by changes in abiotic and biotic conditions which may negatively affect epiphytic lichen abundance [12]. In predominantly managed forests, greater tree mortality, caused by windthrows, is found near clear-cut edges [3]. In fact, this also causes a lack of the substrate availability for epiphytic lichen species. 
When studying the persistence of edge effects, it has to be acknowledged that, at one point, edges and edge effects are not distinguishable. To address this, we did not to set an arbitrary duration of edge effect but rather used our empirical results to indicate the persistence of edge effects.

Since we could not implement long-term measurements of vegetation changes in edges in our study, we used space-for time substitution to infer trends of change from young to old clear-cut edges. We acknowledge the limitations of this approach in comparison to long-term measurements which were not feasible in this study. Our selected sample plots are grouped by development stages which reflect successional stages. However, we have no data on potential local variations in vegetation dynamics which could influence our conclusions.

\section{Conclusions}

The persistence of edge effects, especially from anthropogenic disturbances, is understudied, leaving white spots in our understanding of long-term influence of clear-cut harvesting on biodiversity. In this study, we found that influence from forest harvesting in stands adjacent to A. glutinosa swamp forests diminishes over time-biotic responses show, that edge influence stabilizes after first 20 years since the introduction of clear-cut edges. Natural disturbances in the form of gap dynamics and seasonal water level fluctuations still influence $A$. glutinosa swamp forests, possibly weakening the edge influence captured in this study.

We found that the influence of clear-cut edges was quite pronounced in A. glutinosa stands, despite their relatively stable interior conditions, and overall changes in vegetation clearly show that initial rapid changes diminish visibly after 20 years, and the persistence of edge influence is limited to this period. We also found that medium-old edges showed very few significant differences between variables and thus this category was not useful for reflecting changes in edge persistence.

There is a need to plan the allocation of set-aside patches in production forest landscapes to ensure connectivity over longer period of time, and comprehensive planning of clear-cuts in neighboring areas over time can significantly reduce the impact of edge effect on these set-asides. Generally, this would mean rethinking strategies for voluntary nature conservation in production forests, focusing more on larger, less fragmented and less edge-influenced areas. Unfortunately, current policies of nature conservation in Latvia do not prioritize functional connectivity as an important feature of voluntary set-asides.

Author Contributions: L.L. and I.S. designed the work, L.L., Z.R. and E.D. collected field data, L.L., O.M. analyzed the data, Z.R. and Ā.J. interpreted results, L.L. wrote the manuscript, and Z.R., I.S., Ā.J., O.M. and E.D. substantively revised the manuscript. All authors have read and agreed to the published version of the manuscript.

Funding: This study was financially supported by the ERDF Post-doctoral Research Support Program (project Nr.1.1.1.2/16/I/001) Research application "Balancing ecological interests with increasing demands for natural resources in production forests." (Nr.1.1.1.2/VIAA/2/18/294) to L. Liepa.

Acknowledgments: We thank two anonymous reviewers for their valuable comments that helped to improve our manuscript.

Conflicts of Interest: We declare no conflict of interest.

Appendix A

Table A1. Distribution of mean age and age range of adjacent forest stands.

\begin{tabular}{ccc}
\hline Adjacent Stand Age Group & Mean Age & Range \\
\hline$\leq 20$ years $(n=10)$ & 7.3 & $1-20$ \\
$21-40$ years $(n=10)$ & 31.0 & $21-40$ \\
$\geq 41$ years $(n=10)$ & 63.3 & $41-87$ \\
\hline
\end{tabular}


Table A2. Distribution of species by plant ecological features in young ( $\leq 20$ years), medium-old (21-40 years) and old ( $\geq 41$ years) edges. Average proportion of species is given in percentage, \pm standard error is shown.

\begin{tabular}{|c|c|c|c|c|}
\hline \multirow{2}{*}{ Variable } & \multirow{2}{*}{ Species Group } & \multicolumn{3}{|c|}{ Age Group } \\
\hline & & $\leq 20$ Years & 21-40 Years & $\geq 41$ Years \\
\hline \multirow{6}{*}{ Habitat group } & Boreal species & $24.06 \pm 1.20$ & $35.42 \pm 1.77$ & $26.88 \pm 1.34$ \\
\hline & Nemoral species & $15.73 \pm 0.79$ & $15.81 \pm 0.79$ & $14.85 \pm 0.74$ \\
\hline & Nitrophylus species & $38.08 \pm 1.90$ & $31.57 \pm 1.58$ & $38.05 \pm 1.90$ \\
\hline & Meadow species & $2.81 \pm 0.14$ & $1.50 \pm 0.07$ & $2.88 \pm 0.14$ \\
\hline & Swamp forest species & $17.50 \pm 0.88$ & $14.77 \pm 0.74$ & $15.28 \pm 0.76$ \\
\hline & Adventive species & $1.82 \pm 0.09$ & $0.93 \pm 0.05$ & $2.06 \pm 0.10$ \\
\hline \multirow{6}{*}{ Seed dispersal agent } & Animals & $12.65 \pm 0.63$ & $10.37 \pm 0.52$ & $14.07 \pm 0.70$ \\
\hline & Ants & $7.77 \pm 0.39$ & $8.28 \pm 0.41$ & $7.42 \pm 0.37$ \\
\hline & Autochorous & $9.89 \pm 0.49$ & $8.44 \pm 0.42$ & $1.55 \pm 0.58$ \\
\hline & Birds & $32.94 \pm 1.65$ & $37.45 \pm 1.87$ & $29.28 \pm 1.46$ \\
\hline & Water & $20.10 \pm 1.00$ & $20.05 \pm 1.00$ & $20.42 \pm 1.02$ \\
\hline & Wind & $16.66 \pm 0.83$ & $15.42 \pm 0.77$ & $17.27 \pm 0.86$ \\
\hline \multirow{7}{*}{ Plant strategy group } & $\mathrm{C}$ & $29.05 \pm 1.45$ & $29.43 \pm 1.47$ & $27.17 \pm 1.36$ \\
\hline & CR & $7.08 \pm 0.35$ & $6.94 \pm 0.35$ & $6.13 \pm 0.31$ \\
\hline & CS & $35.52 \pm 1.78$ & $37.48 \pm 1.87$ & $40.32 \pm 2.02$ \\
\hline & CSR & $18.15 \pm 0.91$ & $14.61 \pm 0.73$ & $16.51 \pm 0.83$ \\
\hline & $\mathrm{R}$ & $0.56 \pm 0.03$ & $0.35 \pm 0.02$ & $0.51 \pm 0.03$ \\
\hline & $\mathrm{S}$ & $8.74 \pm 0.44$ & $9.63 \pm 0.48$ & $8.36 \pm 0.42$ \\
\hline & SR & $0.90 \pm 0.04$ & $1.56 \pm 0.08$ & $1.01 \pm 0.05$ \\
\hline \multirow{7}{*}{ Raunkiaer life history form } & Chamaephyte & $9.32 \pm 0.47$ & $11.54 \pm 0.58$ & $10.86 \pm 0.54$ \\
\hline & Geophyte & $10.51 \pm 0.53$ & $11.97 \pm 0.60$ & $12.19 \pm 0.61$ \\
\hline & Helophyte & $16.55 \pm 0.83$ & $17.71 \pm 0.89$ & $18.01 \pm 0.90$ \\
\hline & Hemicryptophyte & $40.90 \pm 2.05$ & $30.26 \pm 1.51$ & $36.40 \pm 1.82$ \\
\hline & Hydrophyte & $0.95 \pm 0.05$ & $0.76 \pm 0.04$ & $0.79 \pm 0.04$ \\
\hline & Phanerophyte & $17.43 \pm 0.87$ & $22.80 \pm 1.14$ & $17.00 \pm 0.85$ \\
\hline & Therophyte & $4.34 \pm 0.22$ & $4.95 \pm 0.25$ & $4.76 \pm 0.24$ \\
\hline
\end{tabular}

Plant strategy groups: C (competitive), CS (competitive-stress tolerant), CR (competitive-ruderal), CSR (competitive-stress tolerant-ruderal).

\section{References}

1. Ries, L.; Fletcher, R.J., Jr.; Battin, J.; Sisk, T.D. Ecological responses to habitat edges: Mechanisms, models, and variability explained. Annu. Rev. Ecol. Evol. Syst. 2004, 35, 491-522. [CrossRef]

2. Harper, K.A.; Lesieur, D.; Bergeron, Y.; Drapeau, P. Forest structure and composition at young fire and cut edges in black spruce boreal forest. Can. J. For. Res. 2004, 34, 289-302. [CrossRef]

3. Harper, K.A.; Macdonald, S.E.; Burton, P.J.; Chen, J.; Brosofske, K.D.; Saunders, S.C.; Euskirchen, E.S.; Roberts, D.A.R.; Jaiteh, M.S.; Esseen, P.A. Edge influence on forest structure and composition in fragmented landscapes. Conserv. Biol. 2005, 19, 768-782. [CrossRef]

4. Hanson, J.J.; Stuart, J.D. Vegetation responses to natural and salvage logged fire edges in Douglas-fir/hardwood forests. For. Ecol. Manag. 2005, 214, 266-278. [CrossRef]

5. Jansson, K.U.; Nilsson, M.; Esseen, P.A. Length and classification of natural and created forest edges in boreal landscapes throughout northern Sweden. For. Ecol. Manag. 2011, 262, 461-469. [CrossRef]

6. Braithwaite, N.T.; Mallik, A.U. Edge effects of wildfire and riparian buffers along boreal forest streams. J. Appl. Ecol. 2012, 49, 192-201. [CrossRef]

7. Harper, K.A.; Macdonald, S.E.; Mayerhofer, M.S.; Biswas, S.R.; Esseen, P.A.; Hylander, K.; Stewart, K.J.; Mallik, A.U.; Drapeau, P.; Jonsson, B.G.; et al. Edge influence on vegetation at natural and anthropogenic edges of boreal forests in Canada and Fennoscandia. J. Ecol. 2015, 103, 550-562. [CrossRef]

8. Laurance, W.F.; Ferreira, L.V.; Rankin-de Merona, J.M.; Laurance, S.G. Rain forest fragmentation and the dynamics of Amazonian tree communities. Ecology 1998, 79, 2032-2040. [CrossRef]

9. Camargo, J.L.; Kapos, V. Complex edge effects on soil moisture and microclimate in central Amazonian forest. J. Trop. Ecol. 1995, 11, 205-221. [CrossRef]

10. Williams-Linera, G. Vegetation structure and environmental conditions of forest edges in Panama. J. Ecol. 1990, 78, 356-373. [CrossRef] 
11. Kruys, N.; Jonsson, B.G. Insular patterns of calicioid lichens in a boreal old-growth forest-wetland mosaic. Ecography 1997, 20, 605-613. [CrossRef]

12. Esseen, P.A.; Renhorn, K.E. Edge effects on an epiphytic lichen in fragmented forests. Conserv. Biol. 2008, 12, 1307-1317. [CrossRef]

13. Moen, J.; Jonsson, B.G. Edge effects on liverworts and lichens in forest patches in a mosaic of boreal forest and wetland. Conserv. Biol. 2003, 17, 380-388. [CrossRef]

14. Hylander, K. Aspect modifies the magnitude of edge effects on bryophyte growth in boreal forests. J. Appl. Ecol. 2005, 42, 518-525. [CrossRef]

15. Chen, J.; Franklin, J.F.; Spies, T.A. Vegetation responses to edge environments in old-growth Douglas-fir forests. Ecol. Appl. 1992, 2, 387-396. [CrossRef]

16. Roberge, J.M.; Bengtsson, S.B.; Wulff, S.; Snäll, T. Edge creation and tree dieback influence the patch-tracking metapopulation dynamics of a red-listed epiphytic bryophyte. J. Appl. Ecol. 2011, 48, 650-658. [CrossRef]

17. Pellissier, V.; Bergès, L.; Nedeltcheva, T.; Schmitt, M.C.; Avon, C.; Cluzeau, C.; Dupouey, J.L. Understorey plant species show long-range spatial patterns in forest patches according to distance-to-edge. J. Veg. Sci. 2013, 24, 9-24. [CrossRef]

18. Baker, T.P.; Baker, S.C.; Dalton, P.J.; Fountain-Jones, N.M.; Jordan, G.J. Temporal persistence of edge effects on bryophytes within harvested forests. For. Ecol. Manag. 2016, 375, 223-229. [CrossRef]

19. Gjerde, I.; Sætersdal, M.; Blom, H.H. Complementary hotspot inventory-A method for identification of important areas for biodiversity at the forest stand level. Biol. Conserv. 2007, 137, 549-557. [CrossRef]

20. Timonen, J.; Siitonen, J.; Gustafsson, L.; Kotiaho, J.S.; Stokland, J.N.; Sverdrup-Thygeson, A.; Mönkkönen, M. Woodland key habitats in northern Europe: Concepts, inventory and protection. Scand. J. For. Res. 2010, 25, 309-324. [CrossRef]

21. Ericsson, T.S.; Berglund, H.; Östlund, L. History and forest biodiversity of woodland key habitats in south boreal Sweden. Biol. Conserv. 2005, 122, 289-303. [CrossRef]

22. Timonen, J.; Gustafsson, L.; Kotiaho, J.S.; Mönkkönen, M. Hotspots in cold climate: Conservation value of woodland key habitats in boreal forests. Biol. Conserv. 2011, 144, 2061-2067. [CrossRef]

23. Aune, K.; Jonsson, B.G.; Moen, J. Isolation and edge effects among woodland key habitats in Sweden: Is forest policy promoting fragmentation? Biol. Conserv. 2005, 124, 89-95. [CrossRef]

24. Paal, J.; Prieditis, N.; Rannik, R.; Jeletsky, E.M. Classification structure of floodplain forests in Estonia: A comparison of two classification approaches. Ann. Bot. Fenn. 2008, 45, 255-268. [CrossRef]

25. Prieditis, N. Alnus glutinosa-dominated wetland forests of the Baltic Region: Community structure, syntaxonomy and conservation. Plant Ecol. 1997, 129, 49-94. [CrossRef]

26. McVean, D.N. Ecology of Alnus Glutinosa (L.) Gaertn.: VII. Establishment of alder by direct seeding of shallow blanket bog. J. Ecol. 1959, 47, 615-618. [CrossRef]

27. Gill, C.J. 1975. The Ecological significance of adventitious rooting as a response to flooding in woody species, with special reference to Alnus glutinosa (L.) Gaertn. Flora 1975, 164, 85-97. [CrossRef]

28. Ahti, T.; Hämet-Ahti, L.; Jalas, J. Vegetation zones and their sections in northwestern Europe. Ann. Bot. Fenn. 1968, 5, 169-211.

29. Latvian Environment, Geology and Meteorology Centre Home Page. Available online: http://www.meteo.lv (accessed on 3 March 2020).

30. Pickett, S.T.A. Space-for-Time Substitution as an Alternative to Long-Term Studies. In Long-Term Studies in Ecology; Likens, G.E., Ed.; Springer: New York, NY, USA, 1989; pp. 110-135.

31. Bušs, K. Latvijas PSR Meža Tipololoǵijas Pamati; LRZTIPI: Rīga, Latvia, 1976.

32. Ek, T.; Suško, U.; Auziňš, R. Mežaudžu Atslēgas Biotopu Inventarizācija. Metodika; Valsts Meža Dienests: Rīga, Latvija, 2002; pp. 1-76.

33. Braun-Blanquet, J. Pflanzensoziologie: Grundzfige der Vegetationskunde; Springer: Wien, Austria, 1964.

34. Gavrilova, G.; Šulcs, V. Flora of Latvian Vascular Plants: List of Taxa; Institute of Biology of University of Latvia: Rīga, Latvia, 1999; pp. 1-136.

35. Ābolina, A.; Piterāns, A.; Bambe, B. Latvijas Kērpji un Sūnas. Taksonu Saraksts; DU AA “Saule”: Salaspils, Latvia, 2015; pp. 1-213, ISBN 978-9984-14-735-2.

36. Magurran, A.E. Ecological Diversity and Its Measurement; Princeton University Press: Princeton, NJ, USA, 1988; pp. 9-79, ISBN 0-691-08485-8.

37. Cain, S.A. Life-forms and phytoclimate. Bot. Rev. 1950, 16, 1-32. [CrossRef] 
38. Hodgson, J.G.; Wilson, P.J.; Hunt, R.; Grime, J.P.; Thompson, K. Allocating CSR plant functional types: A soft approach to a hard problem. Oikos 1999, 85, 282-294. [CrossRef]

39. Kleyer, M.; Bekker, R.M.; Knevel, I.C.; Bakker, J.P.; Thompson, K.; Sonnenschein, M.; Poschlod, P.; Van Groenendael, J.M.; Klimeš, L.; Klimešová, J.; et al. The LEDA traitbase: A database of life-history traits of the northwest European flora. J. Ecol. 2008, 96, 1266-1274. [CrossRef]

40. Fitter, A.H.; Peat, H.J. The ecological flora database. J. Ecol. 1994, 82, 415-425. [CrossRef]

41. Flora for Vascular Plants in Central Russia Home Page. Available online: https://www.impb.ru/eco/index.php (accessed on 1 February 2020).

42. Ellenberg, H.; Weber, H.E.; Düll, R.; Wirth, V.; Werner, W.; Paulissen, D. Zeigerwerte von pflanzen in mitteleuropa. Scr. Geobot. 1992, 18, 1-248.

43. Ministru Kabineta Noteikumi Nr. 396. Noteikumi Par īpaši Aizsargājamo Sugu un Ierobežoti Izmantojamo īpaši Aizsargājamo Sugu Sarakstu. (In Latvian). Available online: http://m.likumi.lv/doc.php?id=12821 (accessed on 17 March 2020).

44. R Development Core Team. A Language and Environment for Statistical Computing; R Foundation for Statistical Computing: Vienna, Austria, 2014. Available online: http://www.R-project.org (accessed on 5 February 2020).

45. Matlack, G.R. Microenvironment variation within and among forest edge sites in the eastern United States. Biol. Conserv. 1993, 66, 185-194. [CrossRef]

46. Marozas, V.; Grigaitis, V.; Brazaitis, G. Edge effect on ground vegetation in clear-cut edges of pine-dominated forests. Scand. J. For. Res. 2005, 20, 43-48. [CrossRef]

47. Matlack, G. Vegetation dynamics of the forest edge-trends in space and successional time. J. Ecol. 1994, 82, 113-123. [CrossRef]

48. Hutchison, B.A.; Matt, D.R. The distribution of solar radiation within a deciduous forest. Ecol. Monogr. 1977, 47, 185-207. [CrossRef]

49. Kneeshaw, D.; Bergeron, Y.; Kuuluvainen, T. Forest ecosystem structure and disturbance dynamics across the circumboreal forest. In The Sage Handbook of Biogeography; Millington, A., Blumler, M., Schickhoff, U., Eds.; Sage: Los Angeles, CA, USA, 2011; pp. 263-280, ISBN 978-141-291-951-7.

50. Brothers, T.S.; Spingarn, A. Forest fragmentation and alien plant invasion of central Indiana old-growth forests. Conserv. Biol. 1992, 6, 91-100. [CrossRef]

51. Hermy, M.; Honnay, O.; Firbank, L.; Grashof-Bokdam, C.; Lawesson, J.E. An ecological comparison between ancient and other forest plant species of Europe, and the implications for forest conservation. Biol. Conserv. 1999, 91, 9-22. [CrossRef]

52. Honnay, O.; Verheyen, K.; Hermy, M. Permeability of ancient forest edges for weedy plant species invasion. For. Ecol. Manag. 2002, 161, 109-122. [CrossRef]

53. Sekgororoane, G.B.; Dilworth, T.G. Relative abundance, richness, and diversity of small mammals at induced forest edges. Can. J. Zool. 1995, 73, 1432-1437. [CrossRef]

54. Lovejoy, T.E.; Bierregaard, R.O., Jr.; Rylands, A.B.; Malcolm, J.R.; Quintela, C.E.; Harper, L.H.; Brown, K.S., Jr.; Powell, A.H.; Powell, G.V.N.; Schubart, H.O.R.; et al. Edge and other effects of isolation on Amazon forest fragments. In Conservation Biology; Soule, M., Ed.; Sinauer Associates: Sunderland, MA, USA, 1986; pp. 257-285, ISBN 978-087-893-794-3.

55. Gignac, L.D.; Dale, M.R. Effects of size, shape, and edge on vegetation in remnants of the upland boreal mixed-wood forest in agro-environments of Alberta, Canada. Botany 2007, 85, 273-284. [CrossRef]

56. Lawes, M.J.; Lamb, B.C.; Boudreau, S. Area-but no edge-effect on woody seedling abundance and species richness in old Afromontane forest fragments. J. Veg. Sci. 2005, 16, 363-372. [CrossRef]

57. Harper, K.A.; Macdonald, S.E. Structure and composition of edges next to regenerating clear-cuts in mixed-wood boreal forest. J. Veg. Sci. 2002, 13, 535-546. [CrossRef]

58. Murcia, C. Edge effects in fragmented forests: Implications for conservation. Trends Ecol. Evol. 1995, 10, 58-62. [CrossRef]

(C) 2020 by the authors. Licensee MDPI, Basel, Switzerland. This article is an open access article distributed under the terms and conditions of the Creative Commons Attribution (CC BY) license (http://creativecommons.org/licenses/by/4.0/). 